\title{
Characteristic Studies of Hexamethylene Diamine Complexes
}

\author{
Hoda A. Bayoumi \\ Chemistry Department, Girls College for Arts, Science and Education, Ain-Shams University, P.O. Box 11757, Cairo, Egypt \\ Correspondence should be addressed to Hoda A. Bayoumi; hodabayoumi@yahoo.com
}

Received 21 July 2013; Accepted 23 August 2013

Academic Editor: W. T. Wong

Copyright (C) 2013 Hoda A. Bayoumi. This is an open access article distributed under the Creative Commons Attribution License, which permits unrestricted use, distribution, and reproduction in any medium, provided the original work is properly cited.

Preparation and chemical analysis of $\mathrm{Mn}(\mathrm{II}), \mathrm{Fe}(\mathrm{III}), \mathrm{Co}(\mathrm{II}), \mathrm{Ni}(\mathrm{II})$, and $\mathrm{Zn}$ (II) complexes with Schiff base $\mathrm{L}$ [o$\left.\mathrm{HOC}_{6} \mathrm{H}_{4} \mathrm{CH}: \mathrm{N}\left(\mathrm{CH}_{2}\right)_{6} \mathrm{~N}: \mathrm{CHC}_{6} \mathrm{H}_{4} \mathrm{OH}-\mathrm{o}\right]$ are the main tasks of this work. The octahedral $\left(\mathrm{M}_{2} \mathrm{~L}_{2} \cdot n \mathrm{H}_{2} \mathrm{O} \cdot \mathrm{X}\right)$ complexes in $1: 1 \mathrm{M}: \mathrm{L}$ ratio $\left(\mathrm{X}=\mathrm{NO}_{3}{ }^{-}\right.$or $\mathrm{Ac}^{-}$group, $\mathrm{L}=$ ligand) were prepared by involving the hydroxylic group in ortho position. All complexes were characterized on the basis of elemental analysis, UV, IR, ${ }^{1} \mathrm{H} \mathrm{NMR}, \mathrm{Gc} / \mathrm{Ms}$, thermogravimetric analysis, magnetic measurements, molar conductance, and electrical conductivity. The obtained data indicate that all the investigated compounds behave as semiconductor materials.

\section{Introduction}

The chemistry of transition metal complexes of Schiff base compounds hasattracted a lot of interest in the field of bioinorganic and coordination chemistry [1-4]. The presence of ion pair on the nitrogen atom of imino group enables the coordination of numerous metal cations [5]. Transition metal complexes with oxygen and nitrogen donor Schiff bases are of particular interest because of their ability to possess unusual configuration that is structurally labile and their sensitivity to molecular environments [6, 7]. Schiff base can also accommodate different anions of the same center metal involving various coordination modes, thereby allowing successful synthesis of homo- and heterometallic complexes with varied stereochemistry. This feature is employed for modeling active sites in biological system [811]. In regard to importance of these compounds, many literatures have been published in this field. In view of this recently, multicomponent has much attention, and many of them have been reported. The desired Schiff base was obtained when 1,6-hexanediamine was condensed with salicylaldehyde. The structures of $\mathrm{Mn}$ (II), Fe(III), Co(II), Ni(II), and $\mathrm{Zn}$ (II) complexes were confirmed by elemental analysis, infrared and UV-Visible spectra, thermogravimetric analysis, magnetic measurements, and molar conductance.

\section{Experimental}

2.1. Physical Measurements. Infrared measurements were carried out on Perkin Elmer spectrophotometer model 1430 in range from 200 to $4000 \mathrm{~cm}^{-1}$. Ultraviolet and visible spectra were carried out on a Perkin Elmer Lambda 35 UV-Vis spectrophotometer in the range $190-500 \mathrm{~nm}$. The solution spectra of ligands and complexes were carried out in $10^{-6} \mathrm{M}$ of DMF. ${ }^{1} \mathrm{H}-\mathrm{NMR}$ spectra were recorded using a Varian spectrometer, $200 \mathrm{MHz}$. Thermal gravimetric analysis (TGA) data were measured from room temperature to $650^{\circ} \mathrm{C}$ at heating rate of $10^{\circ} \mathrm{C} / \mathrm{min}$. The data were obtained using a Shimadzu TGA-50H instrument. Mass spectra of the compounds were recorded on a Hewlett Packard mass spectrometer model MS 5988. Samples were introduced directly to the probe; fragmentations were carried out at $300^{\circ} \mathrm{C}$ and $70 \mathrm{eV}$. Molar conductivities were measured using WAP, GMP 500 conductivity meter. Magnetic susceptibilities of the complexes were measured by the Gouy method at room temperature using a magnetic susceptibility balance, Sherwood Scientific, Cambridge Science Park, Cambridge, UK. Effective magnetic moments were calculated from the expression $\mu_{\text {eff }}=2.84\left(X_{M}\right)^{1 / 2}$ B.M., where $X_{M}$ is molar susceptibility.

2.2. Synthesis of $N, N^{\prime}$-Hexamethylenebis(Salicylideneimine) Schiff Base L (HBS). The ligand was synthesized by slowly adding salicylaldehyde $(5.47 \mathrm{~mL}, 44.86 \mathrm{mmole})$ in $100 \mathrm{~mL}$ methanol to 1,6-hexanediamine ( $3 \mathrm{~g}, 25.81 \mathrm{mmole})$. The reaction mixture was heated to reflux for $2 \mathrm{hr}$. The yellow product obtained was filtered off and washed with few amount of methanol and then diethylether, and fine crystals were 


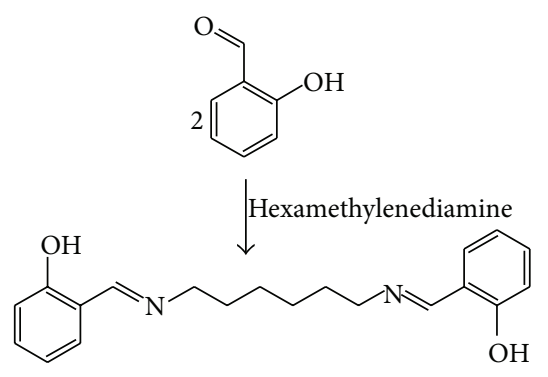

Scheme 1: Schematic representation for the formation of Schiff base ligand L (HBS).

obtained by recrystallization from methanol. The ligand obtained was soluble in 1,2-dichloromethane, chloroform, and partially soluble in methanol and ethanol. The yield was (7 g, 83.73\%), m.p. $72^{\circ} \mathrm{C}$, Calc. for $\mathrm{C}_{20} \mathrm{H}_{24} \mathrm{~N}_{2} \mathrm{O}_{2}$ : C, 74.07; $\mathrm{H}$, 7.41; N, 8.64, Found: C, 73.65; H, 7.77; N, 8.59\%. The reaction for the formation of L (HBS) is illustrated in Scheme 1.

2.3. Synthesis of Schiff Base Metal Complexes: Reaction of $\mathrm{Mn}\left(\mathrm{NO}_{3}\right)_{2} \cdot 6 \mathrm{H}_{2} \mathrm{O}$ with $\mathrm{L}$ (HBS). A pink solution of $\mathrm{Mn}\left(\mathrm{NO}_{3}\right)_{2} \cdot 6 \mathrm{H}_{2} \mathrm{O}(0.42 \mathrm{~mL}, 2 \mathrm{mmole})$ in methanol $(30 \mathrm{~mL})$ was added gradually with constant stirring to a solution of the ligand L (HBS) (0.32 g, 1 mmole) in methanol $(30 \mathrm{~mL})$. The solution was refluxed for $2 \mathrm{hr}$. The dark green precipitate was deposited after evaporation of part of the solvent which was collected and washed with methanol and then diethylether. The product obtained was insoluble in methanol, ethanol, 1,2dichloromethanem, and chloroform but soluble in dimethylsulfoxide and dimethylformamide. The yield was $(0.39 \mathrm{~g}$, $43.64 \%)$, m.p. $>300^{\circ} \mathrm{C}$.

2.4. Reaction of $\mathrm{Fe}\left(\mathrm{NO}_{3}\right)_{3} \cdot 9 \mathrm{H}_{2} \mathrm{O}$ with $\mathrm{L}$ (HBS). A yellow solution of $\mathrm{Fe}\left(\mathrm{NO}_{3}\right)_{3} \cdot 9 \mathrm{H}_{2} \mathrm{O}(0.81 \mathrm{~g}, 2 \mathrm{mmole})$ in methanol $(30 \mathrm{~mL})$ was added gradually with constant stirring to a solution of the ligand L (HBS) $(0.32 \mathrm{~g}, 1 \mathrm{mmole})$ in methanol $(30 \mathrm{~mL})$. The solution was refluxed for $2 \mathrm{hr}$. The color changed to blood red and reddish brown. Precipitate was obtained and washed with small amounts of methanol and then diethylether. The precipitate was insoluble in ethanol, methanol, 1,2-dichloromethane, and acetone but soluble in dimethylformamide and dimethylsulfoxide. The yield was (0.75 g, 66.25\%), m.p. $>300^{\circ} \mathrm{C}$.

2.5. Reaction of $\mathrm{Co}\left(\mathrm{NO}_{3}\right)_{2} \cdot 6 \mathrm{H}_{2} \mathrm{O}$ with $\mathrm{L}$ (HBS). A red solution of $\mathrm{Co}\left(\mathrm{NO}_{3}\right)_{2} \cdot 6 \mathrm{H}_{2} \mathrm{O}(0.58 \mathrm{~g}, 2$ mmole $)$ in methanol $(30 \mathrm{~mL})$ was added gradually with constant stirring to a solution of the ligand L (HBS) (0.32 g, 1 mmole) in methanol $(30 \mathrm{~mL})$. The reaction mixture was refluxed for $2 \mathrm{hr}$. Dark green precipitate was filtered off and dried. The product obtained was insoluble in 1,2-dichloromethane, chloroform, methanol, and ethanol but soluble in dimethylformamide and dimethylsulfoxide. The yield was $(0.27 \mathrm{~g}, 30.23 \%)$, m.p. $>300^{\circ} \mathrm{C}$.

2.6. Reaction of $\mathrm{Ni}\left(\mathrm{NO}_{3}\right)_{2} \cdot 6 \mathrm{H}_{2} \mathrm{O}$ with $\mathrm{L}$ (HBS). A green solution of $\mathrm{Ni}\left(\mathrm{NO}_{3}\right)_{2} \cdot 6 \mathrm{H}_{2} \mathrm{O}(0.58 \mathrm{~g}, 2 \mathrm{mmole})$ in methanol
$(30 \mathrm{~mL})$ was added gradually with constant stirring to a solution of the ligand L (HBS) $(0.32 \mathrm{~g}, 1 \mathrm{mmole})$ in methanol $(30 \mathrm{~mL})$. The solution was refluxed for $2 \mathrm{hr}$. The green precipitate deposited after evaporation. Part of the solvent was collected and washed with small amounts of methanol and then diethylether. The product obtained was insoluble in ethanol, methanol, and 1,2-dichloromethane but soluble in dimethylformamide and dimethylsulfoxide. The yield was (0.32 g, 35.43\%), m.p. $>300^{\circ} \mathrm{C}$.

2.7. Reaction of $\mathrm{Zn}\left(\mathrm{CH}_{3} \mathrm{COO}\right)_{2} \cdot 2 \mathrm{H}_{2} \mathrm{O}$ with $\mathrm{L}$ (HBS). A solution of $\mathrm{Zn}\left(\mathrm{CH}_{3} \mathrm{COO}\right)_{2} \cdot 2 \mathrm{H}_{2} \mathrm{O}(0.44 \mathrm{~g}, 2 \mathrm{mmole})$ in methanol $(30 \mathrm{~mL})$ was added gradually with constant stirring to a solution of the ligand L (HBS) $(0.32 \mathrm{~g}, 1 \mathrm{mmole})$. The solution was refluxed for $2 \mathrm{hr}$. Yellowish white precipitate obtained was filtered and washed with small amount of methanol and then diethylether. The yield was $(0.61 \mathrm{~g}, 78.63 \%)$, m.p. $>300^{\circ} \mathrm{C}$.

\section{Results and Discussion}

All the complexes provide satisfactory $\mathrm{C}, \mathrm{H}, \mathrm{N}$, and metal analyses and confirm the general composition $\left[\mathrm{M}_{2} \mathrm{~L}_{2}\left(\mathrm{H}_{2} \mathrm{O}\right)\right]$ and $\left[\mathrm{M}_{2} \mathrm{~L}_{2} \mathrm{X}_{2}\left(\mathrm{H}_{2} \mathrm{O}\right)\right]$, where $\mathrm{L}=$ ligand, $\mathrm{X}=\mathrm{NO}_{3}{ }^{-}$, or $\mathrm{Ac}^{-}$, $\mathrm{M}=\mathrm{Mn}(\mathrm{II}), \mathrm{Fe}(\mathrm{III}), \mathrm{Ni}(\mathrm{II}), \mathrm{Co}(\mathrm{II})$, and $\mathrm{Zn}(\mathrm{II})$. The isolated solid complexes are stable in air. The analytical and physical properties of the prepared complexes are given in Table 1.

3.1. Electronic Spectral and Magnetic Susceptibility Measurements. The electronic spectrum of $\mathrm{Mn}$ (II) complex shows a band at $721 \mathrm{~nm}$. This band is assignable to $d-d$ transition. The band at $316.52 \mathrm{~nm}$ may be attributed to phenolate $\mathrm{O}(\mathrm{p} \pi) \rightarrow$ $\operatorname{Mn}\left(\mathrm{d} \pi^{*}\right)$ ligand and to metal charge transfer [12]. The band at $256.46 \mathrm{~nm}$ is due to $\pi-\pi^{*}$ (azomethine) ligand transitions. The magnetic moment (5.65 B.M.) is additional evidence for octahedral structure. The conductance of $\mathrm{Mn}$ (II) complex in $\mathrm{DMF}$ is $25.8 \mu \mathrm{S} / \mathrm{cm}$. The low value of conductance indicated that the complex is nonelectrolyte. The electronic spectrum of Fe(III) complex shows a broad band at $415.20 \mathrm{~nm}$. This is mainly due to charge-transfer (CT) band. The absorption bands at 257.7 and $276 \mathrm{~nm}$ are attributed to $\pi-\pi^{*}$ (azomethine) ligand and $n-\pi^{*}$ transitions [13] (see Table 3).

The value of the magnetic moment of the Fe(III) complex is 5.08 B.M. which falls in the range of values corresponding to low-spin octahedral complexes of Fe(III) ions. The conductance of Fe(III) complex in DMF is $7.18 \mu \mathrm{S} / \mathrm{cm}$. The low value of conductance indicated that the complex is nonelectrolyte.

The electronic spectrum of the green $\mathrm{Ni}(\mathrm{II})$ complex showed three bands. The spectrum of octahedral $\mathrm{Ni}$ (II) consists of three bands which are accordingly assigned as ${ }^{3} \mathrm{~A}_{2} \mathrm{~g}(\mathrm{~F}) \rightarrow{ }^{3} \mathrm{~T}_{2} \mathrm{~g}(\mathrm{~F}), \quad{ }^{3} \mathrm{~A}_{2} \mathrm{~g}(\mathrm{~F}) \rightarrow{ }^{3} \mathrm{~T}_{1} \mathrm{~g}(\mathrm{~F})$, and ${ }^{3} \mathrm{~A}_{2} \mathrm{~g}(\mathrm{~F}) \rightarrow{ }^{3} \mathrm{~T}_{1} \mathrm{~g}(\mathrm{P})$. The ${ }^{3} \mathrm{~A}_{2} \mathrm{~g}(\mathrm{~F}) \rightarrow{ }^{3} \mathrm{~T}_{2} \mathrm{~g}(\mathrm{~F})$ transition was not observed due to the fact that it occurs in the near infrared and is out of the range of the used instrument. The ${ }^{3} \mathrm{~A}_{2} \mathrm{~g}(\mathrm{~F}) \rightarrow{ }^{3} \mathrm{~T}_{1} \mathrm{~g}(\mathrm{~F})$ transition is observed at $734.91 \mathrm{~nm}$. The third band due to ${ }^{3} \mathrm{~A}_{2} \mathrm{~g}(\mathrm{~F}) \rightarrow{ }^{3} \mathrm{~T}_{1} \mathrm{~g}(\mathrm{P})$ is observed at $369.73 \mathrm{~nm}$, which refers to the charge-transfer transition.

The value of the magnetic moment of $\mathrm{Ni}$ (II) complex is $2.52 \mathrm{~B} . \mathrm{M}$. The conductance of $\mathrm{Ni}(\mathrm{II})$ complex in DMF is 


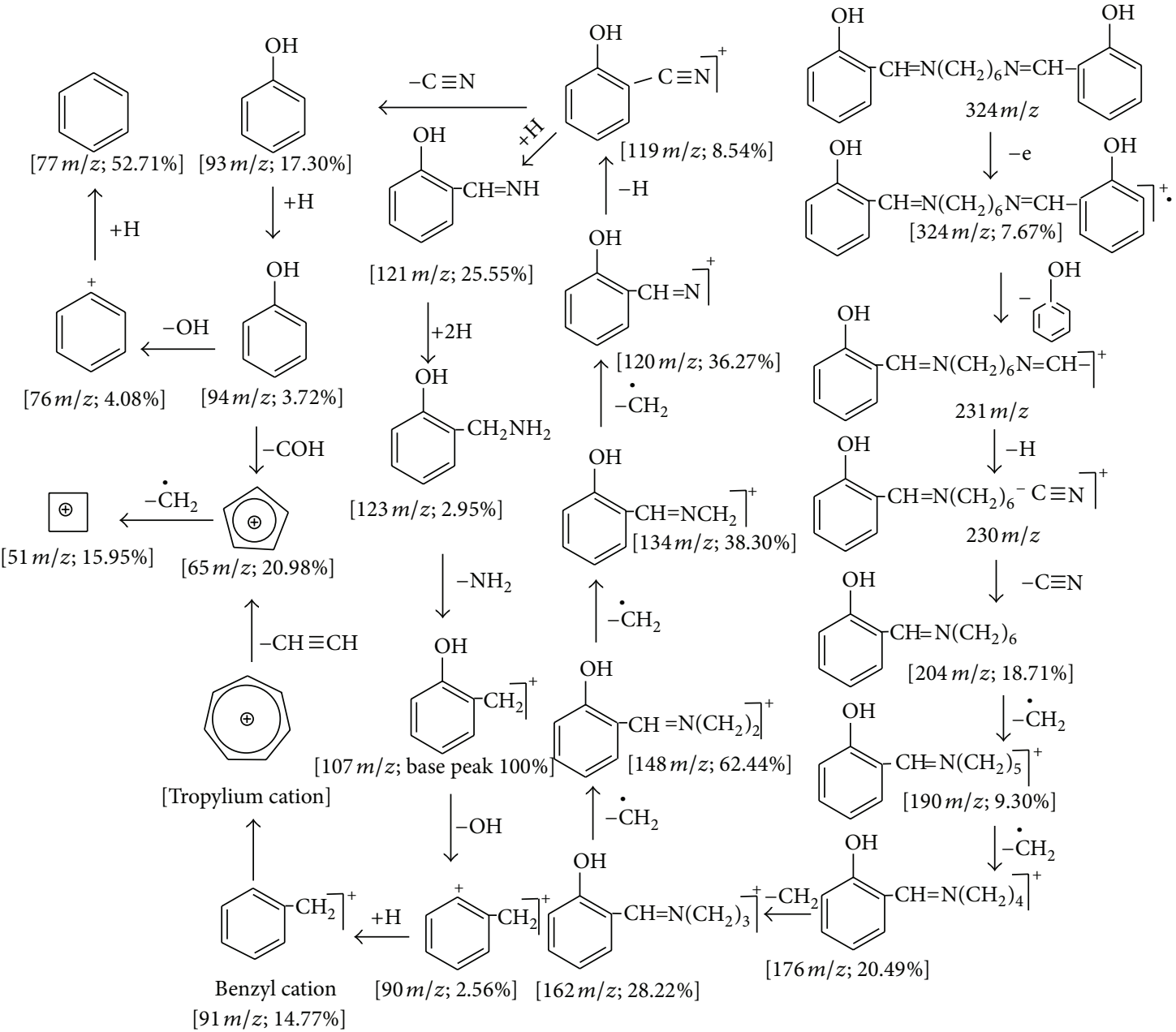

SCHEME 2: Mass fragmentation pattern of the Schiff base L (HBS), ligand.

TABLE 1: Physical data of ligand (HBS) and corresponding metal complexes.

\begin{tabular}{|c|c|c|c|c|c|c|c|}
\hline \multirow{2}{*}{$\begin{array}{l}\text { Ligand/complex } \\
\text { Mol. formula }\end{array}$} & \multirow{2}{*}{ (Yield) \% M.wt } & \multirow{2}{*}{ Colour } & \multirow{2}{*}{$\begin{array}{c}\text { M.P. }{ }^{\circ} \mathrm{C} \\
(\mathrm{L}: \mathrm{M})\end{array}$} & \multicolumn{4}{|c|}{ Elemental analyses (Found) Calc. \% } \\
\hline & & & & $\mathrm{C}$ & $\mathrm{H}$ & $\mathrm{N}$ & $\mathrm{M}$ \\
\hline L (HBS) & $(83.73)$ & \multirow{2}{*}{ Yellow } & \multirow{2}{*}{72} & $(73.65)$ & $(7.77)$ & $(8.59)$ & \\
\hline $\mathrm{C}_{20} \mathrm{H}_{24} \mathrm{~N}_{2} \mathrm{O}_{2}$ & 324 & & & 74.07 & 7.41 & 8.64 & \\
\hline $1-\left[\mathrm{Mn}_{2}(\mathrm{~L})_{2}\left(\mathrm{H}_{2} \mathrm{O}\right)_{4}\right]$ & $(43.64)$ & \multirow{2}{*}{$\begin{array}{l}\text { Dark } \\
\text { green }\end{array}$} & \multirow{2}{*}{$\begin{array}{l}>300 \\
(1: 2)\end{array}$} & $(57.59)$ & $(5.76)$ & $(6.51)$ & $(12.67)$ \\
\hline $\mathrm{C}_{40} \mathrm{H}_{52} \mathrm{~N}_{4} \mathrm{O}_{8} \mathrm{Mn}_{2}$ & 826.08 & & & 58.10 & 6.29 & 6.77 & 13.33 \\
\hline 2- $\left[\mathrm{Fe}_{2}\left(\mathrm{H}_{2} \mathrm{~L}\right)\left(\mathrm{NO}_{3}\right)_{6}\left(\mathrm{H}_{2} \mathrm{O}\right)_{2}\right] \cdot 6 \mathrm{H}_{2} \mathrm{O}$ & $(66.25)$ & \multirow{2}{*}{$\begin{array}{l}\text { Reddish } \\
\text { brown }\end{array}$} & \multirow{2}{*}{$\begin{array}{l}>300 \\
(1: 2)\end{array}$} & $(24.6)$ & $(3.95)$ & $(10.9)$ & $(12.08)$ \\
\hline $\mathrm{C}_{20} \mathrm{H}_{40} \mathrm{~N}_{8} \mathrm{O}_{28} \mathrm{Fe}_{2}$ & 952 & & & 25.21 & 4.20 & 11.76 & 11.76 \\
\hline $3-\left[\mathrm{Co}_{2}(\mathrm{HL})_{2}\left(\mathrm{NO}_{3}\right)_{2}\left(\mathrm{H}_{2} \mathrm{O}\right)_{2}\right]$ & $(30.23)$ & \multirow{2}{*}{$\begin{array}{c}\text { Dark } \\
\text { green }\end{array}$} & \multirow{2}{*}{$\begin{array}{l}>300 \\
(1: 1)\end{array}$} & $(50.67)$ & $(5.35)$ & $(9.70)$ & $(13.08)$ \\
\hline $\mathrm{C}_{40} \mathrm{H}_{50} \mathrm{~N}_{6} \mathrm{O}_{12} \mathrm{Co}_{2}$ & 923.8 & & & 51.95 & 5.41 & 9.09 & 12.70 \\
\hline 4- $\left[\mathrm{Ni}_{2}(\mathrm{~L})\left(\mathrm{NO}_{3}\right)_{2}\left(\mathrm{H}_{2} \mathrm{O}\right)_{6}\right]$ & $(35.43)$ & \multirow{2}{*}{ Green } & \multirow{2}{*}{$\begin{array}{l}>300 \\
(1: 2)\end{array}$} & $(36.12)$ & $(4.19)$ & $(8.76)$ & $(17.83)$ \\
\hline $\mathrm{C}_{20} \mathrm{H}_{34} \mathrm{~N}_{4} \mathrm{O}_{14} \mathrm{Ni}_{2}$ & 671.4 & & & 35.75 & 5.05 & 8.33 & 17.49 \\
\hline $5-\left[\mathrm{Cu}_{2}(\mathrm{HL})_{2}(\mathrm{Ac})_{2}\left(\mathrm{H}_{2} \mathrm{O}\right)_{2}\right]$ & $(47.00)$ & Dark & $>300$ & $(57.06)$ & $(5.94)$ & $(6.70)$ & $(13.80)$ \\
\hline $\mathrm{C}_{44} \mathrm{H}_{56} \mathrm{~N}_{4} \mathrm{O}_{10} \mathrm{Cu}_{2}$ & 927.3 & green & $(1: 1)$ & 56.95 & 6.04 & 6.04 & 13.70 \\
\hline $6-\left[\mathrm{Zn}_{2}(\mathrm{HL})_{2}(\mathrm{Ac})_{2}\left(\mathrm{H}_{2} \mathrm{O}\right)_{2}\right]$ & $(78.63)$ & Yellowish & $>300$ & $(57.55)$ & $(5.10)$ & $(6.24)$ & $(13.41)$ \\
\hline $\mathrm{C}_{40} \mathrm{H}_{48} \mathrm{~N}_{4} \mathrm{O}_{6} \mathrm{Zn}_{2}$ & 930.8 & white & $(1: 1)$ & 56.72 & 6.01 & 6.02 & 13.85 \\
\hline
\end{tabular}



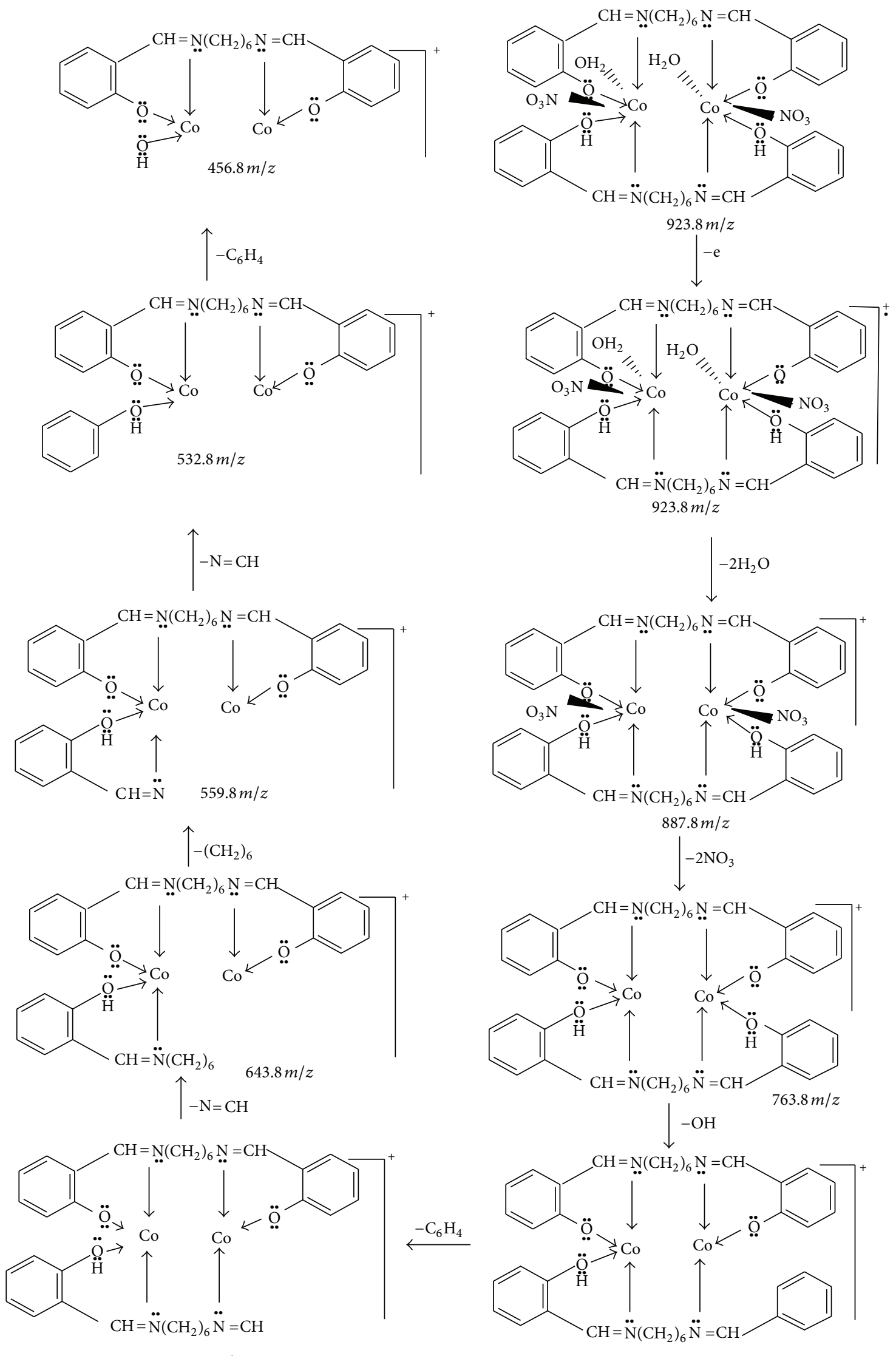

$670.8 \mathrm{~m} / \mathrm{z}$

$746.8 \mathrm{~m} / \mathrm{z}$

Scheme 3: Continued. 


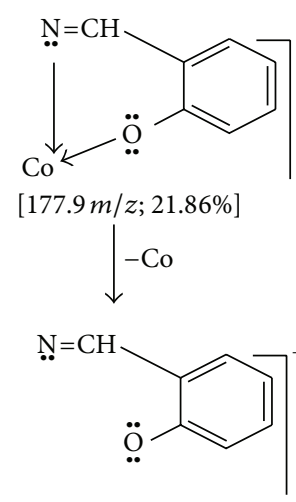

$[119 \mathrm{~m} / z ; 5.02 \%]$<smiles>C[InH][14CH2]c1ccc(O)c(C#N)c1</smiles>

[120 $\mathrm{m} / z ; 29.09 \%$ ]<smiles>C=NCC</smiles><smiles>[C+]1C=CC=CC1</smiles>

$[93 \mathrm{~m} / z ; 8.81 \%]$<smiles>CC(O)(O)c1ccccc1</smiles>

$[76 \mathrm{~m} / z ; 8.81 \%]$<smiles>Cc1ccccc1</smiles>

[77 $m / z ; 33.02 \%]$

$\downarrow-\mathrm{CH} \equiv \mathrm{CH}$

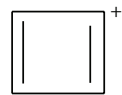

[51 $\mathrm{m} / z ; 11.99 \%$ ]<smiles>CN1CCCCC1=[Ge]Oc1ccccc1</smiles>

[191.9 $\mathrm{m} / z ; 27.27 \%$ ]

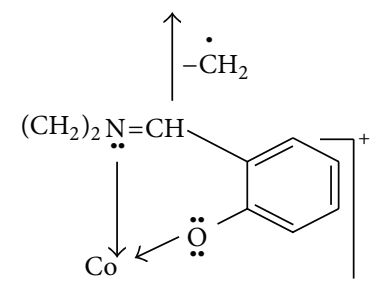

[205.9 $/ z ; 13.79 \%$ ]<smiles></smiles><smiles></smiles>

[219.9 $\mathrm{m} / z ; 13.85 \%]$<smiles>CN=c1c2ccccc2oc(=O)n1C</smiles>

[233.9 $\mathrm{m} / \mathrm{z} ; 20.63 \%]$

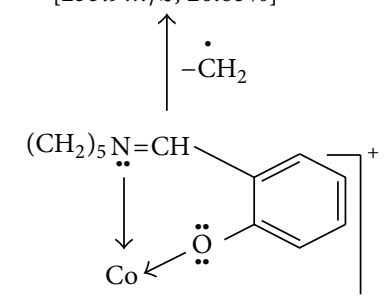

[247.9 $\mathrm{m} / \mathrm{z} ; 13.77 \%]$

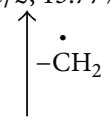

$\mathrm{CH}=\mathrm{N}\left(\mathrm{CH}_{2}\right)_{6} \mathrm{~N}=\mathrm{CH}$<smiles></smiles>

[261.9 $\mathrm{m} / \mathrm{z} ; 8.33 \%]$

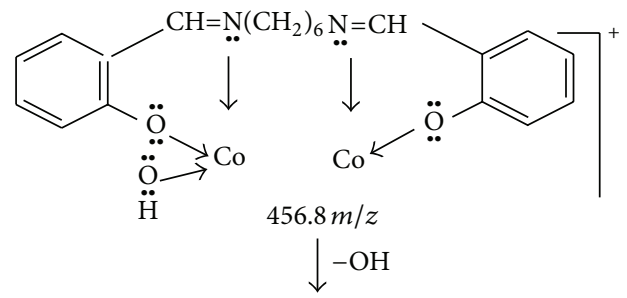

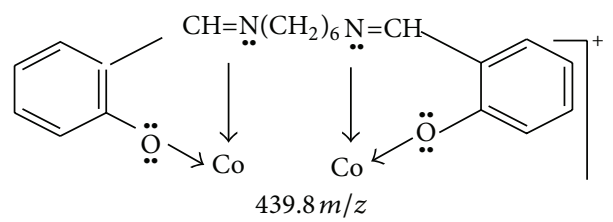<smiles>C1CCCC1</smiles>

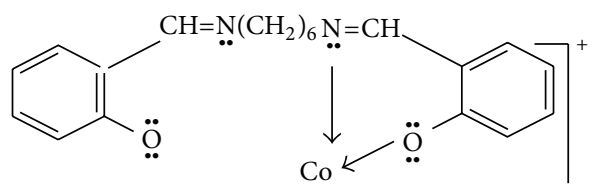

[380.9 $\mathrm{m} / z ; 5.55 \%$ ]

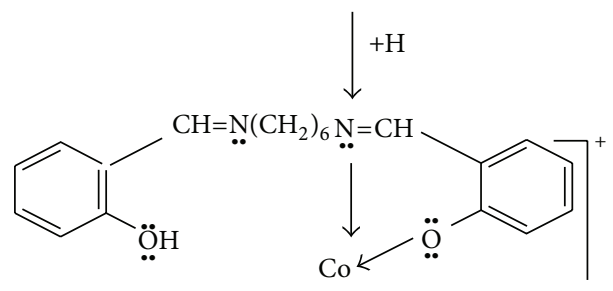

[381.9 $\mathrm{m} / z ; 100 \%$ ] base peak<smiles>CCO</smiles><smiles>Cc1ccccc1</smiles>

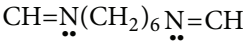

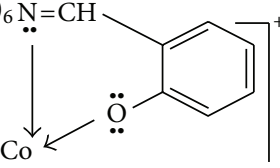

[364.9 $\mathrm{m} / z ; 8.33 \%$ ]<smiles>CCCCCC</smiles>

$\longleftarrow$ - $=\mathrm{CH}$ $\mathrm{CH}=\mathrm{N}\left(\mathrm{CH}_{2}\right)_{6} \mathrm{~N}=\mathrm{CH}$<smiles>N#COc1ccccc1OC1CCCCC1</smiles>

[288.9 $\mathrm{m} / z ; 1.34 \%]$

SCHEme 3: Mass fragmentation pattern of $\left[\mathrm{Co}_{2}(\mathrm{HL})_{2}\left(\mathrm{NO}_{3}\right)_{2}\left(\mathrm{H}_{2} \mathrm{O}\right)_{2}\right]$. 

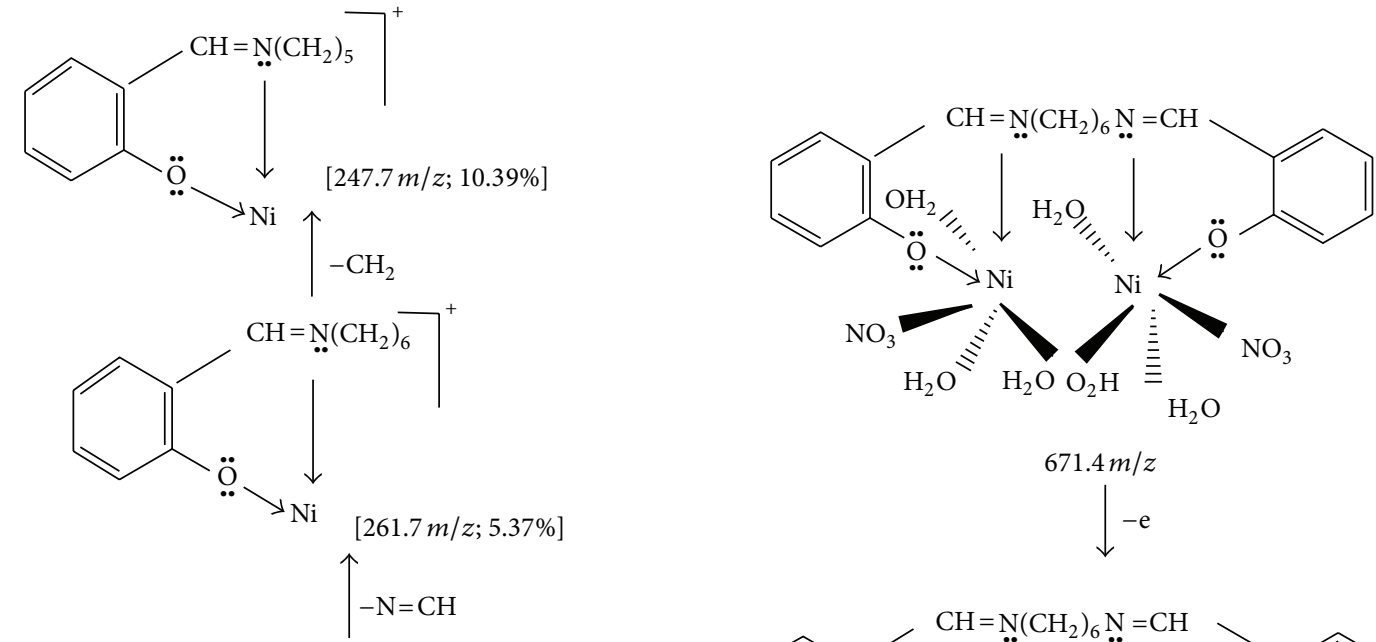

$671.4 \mathrm{~m} / \mathrm{z}$

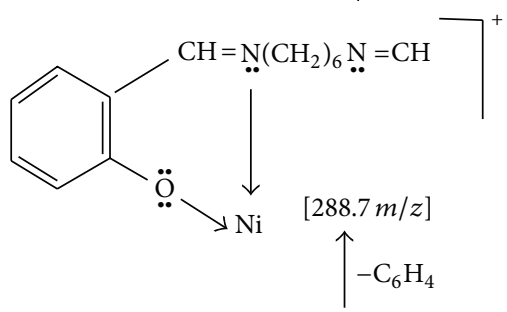<smiles>Cc1ccccc1ONC(N)=NCc1ccccc1</smiles><smiles>Cc1ccccc1ON=CN=NCC(O)Cc1ccccc1O</smiles>

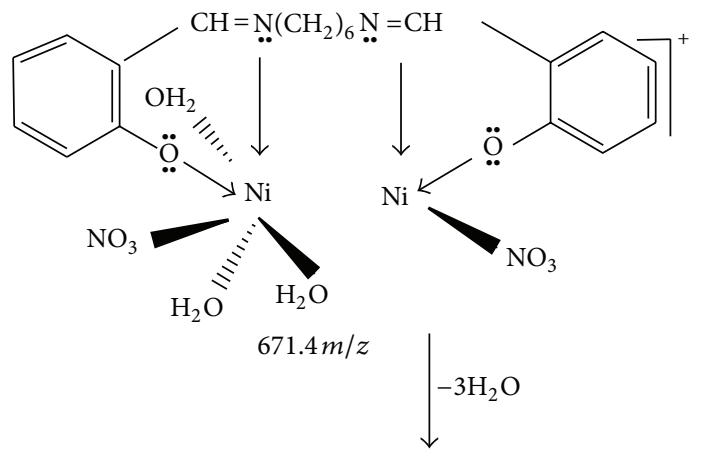

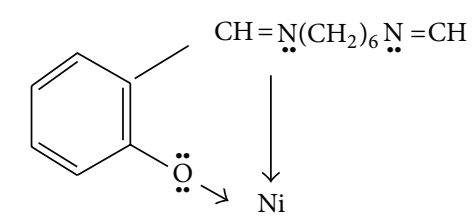<smiles>Cc1ccccc1C</smiles>

[380.7 m/ $z ; 100 \%]$ base peak<smiles>C1CCCC1</smiles><smiles>Cc1ccccc1ON=NCN(C)Cc1ccccc1ON</smiles>

$\stackrel{-\mathrm{NO}_{3}}{\longleftarrow}$

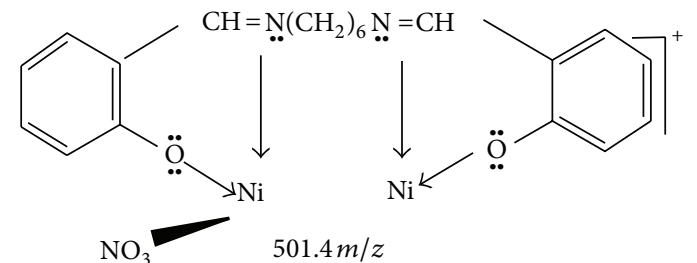
$439.4 \mathrm{~m} / \mathrm{z}$

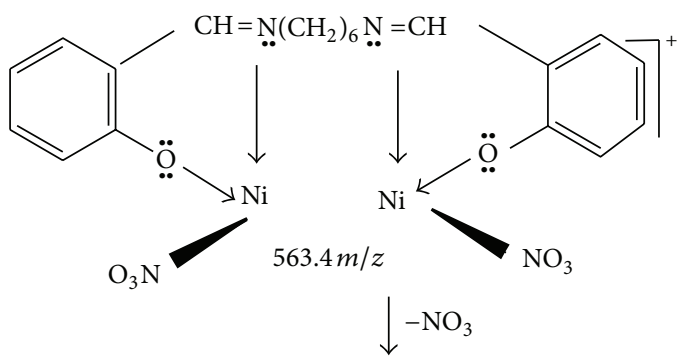

Scheme 4: Continued. 

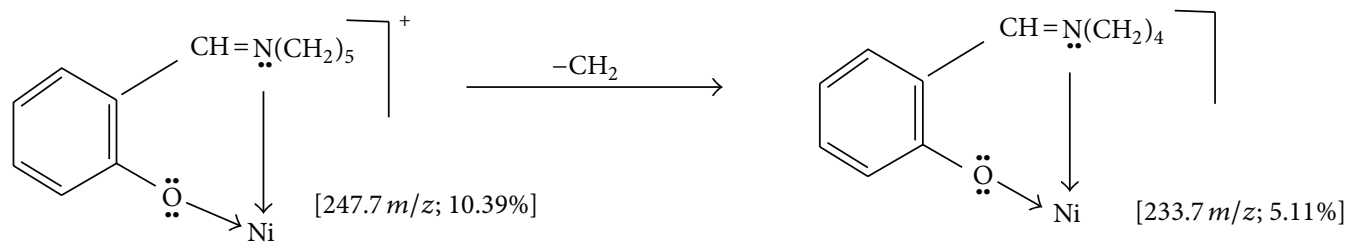

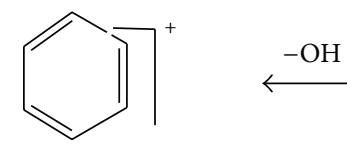

$[76 \mathrm{~m} / z ; 4.17 \%]$<smiles></smiles><smiles>c1ccccc1</smiles>

[77 $\mathrm{m} / z ; 33.83 \%$ ]

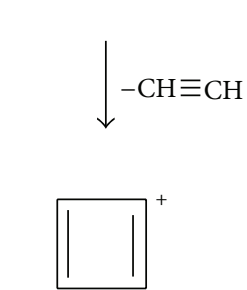

[51 $\mathrm{m} / \mathrm{z} ; 7.42 \%$ ]<smiles>[O]c1ccccc1</smiles>

$[93 ; 16.20 \% \mathrm{~m} / z]$ $+\mathrm{H}$<smiles>CCc1ccccc1</smiles>

[92.7 $\mathrm{m} / \mathrm{z} ; 16.53 \%]$<smiles>CCNOc1ccccc1</smiles>

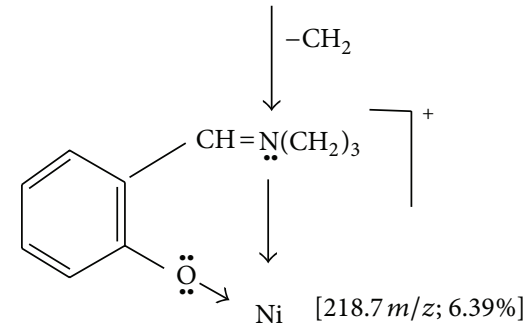

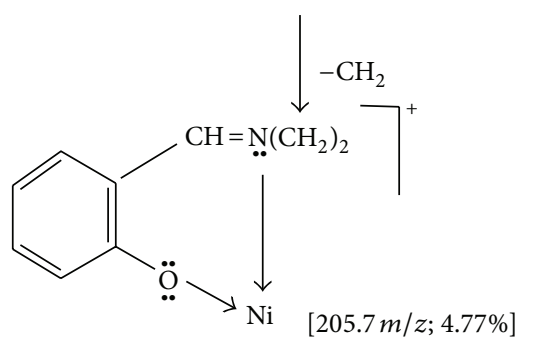<smiles>CCCC</smiles>

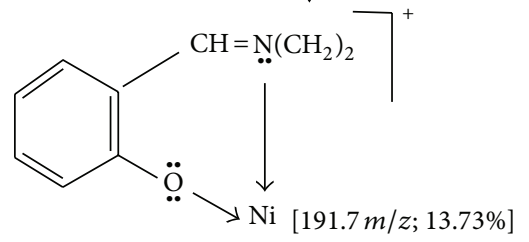

$-\mathrm{HC}=\mathrm{N}$<smiles>CNOc1ccccc1C=NCC#N</smiles>

SCHeme 4: Mass fragmentation pattern of $\left[\mathrm{Ni}_{2}(\mathrm{~L})\left(\mathrm{NO}_{3}\right)_{2}\left(\mathrm{H}_{2} \mathrm{O}\right)_{6}\right]$.

$4.20 \mu \mathrm{S} / \mathrm{cm}$. The low value of conductance indicated that complex is nonelectrolyte.

$\mathrm{Zn}$ (II) chelate is diamagnetic and has octahedral geometry, and the electronic spectra show absorption bands at $367.24 \mathrm{~nm}$ attributed to charge transfer. The conductance of $\mathrm{Zn}(\mathrm{II})$ and complexes in DMF is $6.12 \mu \mathrm{S} / \mathrm{cm}$. The low value of conductance indicated that complex is nonelectrolyte. Electronic spectral studies, magnetic studies and conductance of the metal complexes of ligand L (HBS) are given in Table 4.

3.2. IR Spectra. Chemical reaction at the amino group of $1,6-$ hexanediamine with salicylaldehyde would affect massively the molecular symmetry of 1,6-hexanediamine. The infrared spectrum of 1,6-hexanediamine is therefore basically retained for the reaction product. Some spectral changes are expected to appear as being associated with the formation of new species at the expense of vanished amino group. Confirming this is the disappearance of the vibrational absorptions characteristic of the amino group at $3200 \mathrm{~cm}^{-1}$ and $3120 \mathrm{~cm}^{-1}$ (asymmetric and symmetric of $\mathrm{NH}_{2}$ group, resp.). Consistent with the shift and change of intensity for methylene group at $2930 \mathrm{~cm}^{-1}$ and $2854 \mathrm{~cm}^{-1}$ asymmetric and symmetric of $\mathrm{CH}_{2}, 1460 \mathrm{~cm}^{-1}$ corresponding $\delta$ asymmetric $\mathrm{CH}_{2}$ in plane bending, $1400 \mathrm{~cm}^{-1} \delta$ symmetric $\mathrm{CH}_{2}$ in plane bending and $881 \mathrm{~cm}^{-1}$ ( $\gamma \mathrm{CH}_{2}$ out of plane deformation). At the expense of vanished amino group species, new spectral absorption 
TABLE 2: Important IR bands of HBS ligand and its complexes (1-6) with their assignments.

\begin{tabular}{|c|c|c|c|c|c|c|c|c|c|}
\hline Ligand/complex & $v_{\mathrm{OH}}$ & $\begin{array}{c}\nu_{\mathrm{CH}} \\
\text { aromatic }\end{array}$ & $\begin{array}{c}v_{\mathrm{CH}} \\
\text { sym./aysm. }\end{array}$ & $v_{\mathrm{C}=\mathrm{N}}$ & $v_{\mathrm{C}-\mathrm{O}}$ & $v_{\mathrm{M}-\mathrm{N}}$ & $\nu_{\mathrm{M}-\mathrm{O}}$ & $v_{\mathrm{NO}_{3}}^{-}$ & $v_{\mathrm{Ac}^{-}}$ \\
\hline L (HBS) & 3445 (br) & $3061(w)$ & $\begin{array}{l}2931(\mathrm{~m}) \\
2897(\mathrm{w})\end{array}$ & 1631 (v.s) & $1162(w)$ & - & - & - & - \\
\hline $1-\left[\mathrm{Mn}_{2}(\mathrm{~L})_{2}\left(\mathrm{H}_{2} \mathrm{O}\right)_{4}\right]$ & 3399 (br) & 3052 (v.w) & $\begin{array}{l}2927(\mathrm{~m}) \\
2856(\mathrm{w})\end{array}$ & 1608 (v.s) & $1145(\mathrm{~m})$ & 454 (v.w) & $407(w)$ & - & - \\
\hline $2-\left[\mathrm{Fe}_{2}\left(\mathrm{H}_{2} \mathrm{~L}\right)\left(\mathrm{NO}_{3}\right)_{6}\left(\mathrm{H}_{2} \mathrm{O}\right)_{2}\right] \cdot 6 \mathrm{H}_{2} \mathrm{O}$ & $3356(\mathrm{br})$ & - & $\begin{array}{l}2919(w) \\
2851(w)\end{array}$ & $1629(\mathrm{~m})$ & $1047(w)$ & 581 (v.w) & $427(\mathrm{~m})$ & $\begin{array}{c}1382(\mathrm{~s}) \\
1047(\mathrm{w}) \\
837(\mathrm{w})\end{array}$ & - \\
\hline $3-\left[\mathrm{Co}_{2}(\mathrm{HL})_{2}\left(\mathrm{NO}_{3}\right)_{2}\left(\mathrm{H}_{2} \mathrm{O}\right)_{2}\right]$ & 3425 (br) & 3056 (v.w) & $\begin{array}{l}2924(\mathrm{~m}) \\
2854(\mathrm{w})\end{array}$ & 1614 (v.s) & $1139(\mathrm{w})$ & $586(w)$ & 463 (v.w) & $\begin{array}{c}1320 \mathrm{~m} \\
1028(\mathrm{w}) \\
850(\mathrm{w})\end{array}$ & - \\
\hline $4-\left[\mathrm{Ni}_{2}(\mathrm{~L})\left(\mathrm{NO}_{3}\right)_{2}\left(\mathrm{H}_{2} \mathrm{O}\right)_{6}\right]$ & 3424 (br) & - & $\begin{array}{l}2925(\mathrm{~m}) \\
2856(\mathrm{w})\end{array}$ & $1616(s)$ & $1142(w)$ & $462(w)$ & $395(w)$ & $\begin{array}{c}1323(\mathrm{w}) \\
1039(\mathrm{w}) \\
754(\mathrm{w})\end{array}$ & - \\
\hline $5-\left[\mathrm{Cu}_{2}(\mathrm{HL})_{2}(\mathrm{Ac})_{2}\left(\mathrm{H}_{2} \mathrm{O}\right)_{2}\right]$ & 3446 (br) & 3020 (v.w) & $\begin{array}{l}2919(\mathrm{~m}) \\
2849(\mathrm{w})\end{array}$ & 1624 (v.s) & $1147(\mathrm{~m})$ & $522(\mathrm{w})$ & 470.(w) & - & $\begin{array}{r}1535(\mathrm{~s}) \\
1347(\mathrm{w})\end{array}$ \\
\hline $6-\left[\mathrm{Zn}_{2}(\mathrm{HL})_{2}(\mathrm{Ac})_{2}\left(\mathrm{H}_{2} \mathrm{O}\right)_{2}\right]$ & 3418 (br) & 3011 (v.w) & $\begin{array}{l}2922(\mathrm{~m}) \\
2850(\mathrm{~m})\end{array}$ & 1622 (v.s) & $1188(\mathrm{~m})$ & $457(w)$ & $411(\mathrm{~m})$ & - & $\begin{array}{r}1535(\mathrm{~s}) \\
1347(\mathrm{w})\end{array}$ \\
\hline
\end{tabular}

TABLE 3: Electronic spectral data of Mn(II), Fe(III), Co(II), Ni(II), Cu(II), and Zn(II)-HBS complexes.

\begin{tabular}{lcccc}
\hline Complex & $\pi \rightarrow \pi^{*}, n \rightarrow \pi^{*}$ and C.T. $(\mathrm{nm})$ & $\begin{array}{c}\mathrm{d}-\mathrm{d} \\
\text { transition }\end{array}$ & Magnetic moment & Conductance $\mu$ S/cm \\
\hline $1-\left[\mathrm{Mn}_{2}(\mathrm{~L})_{2}\left(\mathrm{H}_{2} \mathrm{O}\right)_{4}\right]$ & 256,316 & 987.19 & 5.65 & 25.8 \\
$2-\left[\mathrm{Fe}_{2}\left(\mathrm{H}_{2} \mathrm{~L}\right)\left(\mathrm{NO}_{3}\right)_{6}\left(\mathrm{H}_{2} \mathrm{O}\right)_{2}\right] \cdot 6 \mathrm{H}_{2} \mathrm{O}$ & $257,276,415$ & - & 5.08 & 7.18 \\
$3-\left[\mathrm{Co}_{2}(\mathrm{HL})_{2}\left(\mathrm{NO}_{3}\right)_{2}\left(\mathrm{H}_{2} \mathrm{O}\right)_{2}\right]$ & 247,271 & - & 656 & 3.87 \\
$4-\left[\mathrm{Ni}_{2}(\mathrm{~L})\left(\mathrm{NO}_{3}\right)_{2}\left(\mathrm{H}_{2} \mathrm{O}\right)_{6}\right]$ & $267,322,369$ & 734 & 2.52 & 4.20 \\
$5-\left[\mathrm{Cu}_{2}(\mathrm{HL})_{2}(\mathrm{Ac})_{2}\left(\mathrm{H}_{2} \mathrm{O}\right)_{2}\right]$ & $272,305,363$ & 697 & 2.73 & 4.86 \\
$6-\left[\mathrm{Zn}_{2}(\mathrm{HL})_{2}(\mathrm{Ac})_{2}\left(\mathrm{H}_{2} \mathrm{O}\right)_{2}\right]$ & 298,367 & - & 0.93 & 6.12 \\
\hline
\end{tabular}

(Figure 1) appears to be associated with the newly formed species. Consistent with this is the appearance of new absorption at $3445 \mathrm{~cm}^{-1}$ (broad) characteristic of $\nu_{\mathrm{OH}}$ stretch and appear anew absorption band at $1631 \mathrm{~cm}^{-1}$ characteristic of $v_{\mathrm{C}=\mathrm{N}}$ stretch. Also vibrational absorption characteristic of the benzene ring vibrations and $\mathrm{OH}$ should therefore appear to confirm the chemical reaction. Indeed, new characteristic absorption bands appear at 1502 and $1460 \mathrm{~cm}^{-1}$ which are characteristic of the benzene ring vibration. New absorption appear at 1280 and $763 \mathrm{~cm}^{-1}$ can be assigned to the deformation consistent with this is the appearance of new absorption characteristic of $\nu_{\mathrm{C}-\mathrm{O}}$ which appears at $1211 \mathrm{~cm}^{-1}$. The most important bands in the IR spectrum of the complexes are compared to their ligands in Table 2 along with their tentative assignment. The positions of these bands provide significant indications regarding the bonding sites of the ligand molecule when complexed to metal cations, hydroxyl group in ortho position, and imino group. The $\nu_{\mathrm{OH}}$ band at $3445 \mathrm{~cm}^{-1}$ is absent from the IR spectra of the ligand which overlapped with $\mathrm{H}_{2} \mathrm{O}$ coordinate, but it can be indicated by shift of the $v_{\mathrm{C}-\mathrm{O}}$ band. But the $v_{\mathrm{OH}}\left(\mathrm{H}_{2} \mathrm{O}\right.$ coordination $)$ at $3421 \mathrm{~cm}^{-1}$ is present, indicating that central metal is coordinated by water molecule and $\mathrm{OH}$ in ortho position. This coordination is confirmed by the presence of two new bands in the range of $v_{\mathrm{M}-\mathrm{O}}$ therefore different of nature of oxygen. Further in the spectrum of ligand the medium band observed at $1631 \mathrm{~cm}^{-1}$ can be characterized by $v_{\mathrm{C}=\mathrm{N}}$ frequency. This vibrational absorption characteristic to $\mathrm{C}=\mathrm{N}$ shift towards lower wave number by $20-35 \mathrm{~cm}^{-1}$ Table 2 in the spectra of all metal complexes, suggesting the coordination of nitrogen of the azomethine group to central metal atom these complexes consistent with this the metal-nitrogen bond are indicated by the absorptions in the region $454-586 \mathrm{~cm}^{-1}$ from IR data $[14,15]$, it can be inferred that the (L) 1,6-hexanediamine function as bidentate at each end of $\mathrm{L}$ through their hydroxyl oxygen and azomethine $\mathrm{N}$ atom. Also, all the complexes show bands due to the metal-nitrogen and metal-oxygen bonds.

The $\mathrm{NO}_{3}{ }^{-}$ion is coordinated to the metal ion as unidentate in case of complexes (1), (2), (3), and (4) with $\mathrm{C}_{2} v$ symmetry. Each unidentate nitrate group has three nondegenerate modes of vibrations $\left(v_{s}, v_{s}^{\prime}\right.$, and $\left.v_{\text {as }}\right)$ which appeared in the ranges (1315-1360), (1040-1028), and (810-830) $\mathrm{cm}^{-1}[16]$.

On the other hand, acetate anion can, however, coordinate in monodentate, bidentate, or bridging bidentate 
TABLE 4: Solid State of the Elictrical Conductivity for ligand (HBS) and its metal complexes(1-6)

\begin{tabular}{lcccccc}
\hline Compound & $\mathrm{Tc}\left({ }^{\circ} \mathrm{K}\right)$ & $E_{1}(\mathrm{eV})$ at lower temp. & $E_{2}(\mathrm{eV})$ at higher temp. & $\sigma_{1}\left(\Omega^{-1} \mathrm{~cm}^{-1}\right)$ at $298 \mathrm{~K}$ & $\sigma_{2}\left(\Omega^{-1} \mathrm{~cm}^{-1}\right)$ & at higher temp $\left({ }^{\circ} \mathrm{K}\right)$ \\
\hline $\mathrm{L}(\mathrm{HBS})$ & - & - & 0.0116 & $1.435 \times 10^{-11}$ & $5.622 \times 10^{-10}$ & 339 \\
$\mathrm{Mn}(\mathrm{II})$ & $378 \mathrm{~K}$ & 0.062 & 1.945 & $3.708 \times 10^{-11}$ & $2.233 \times 10^{-8}$ & 404 \\
$\mathrm{Fe}(\mathrm{III})$ & $369 \mathrm{~K}$ & 0.098 & 0.540 & $1.035 \times 10^{-10}$ & $1.289 \times 10^{-8}$ & 530 \\
$\mathrm{Co}(\mathrm{II})$ & $488 \mathrm{~K}$ & 0.0039 & 1.848 & $1.370 \times 10^{-11}$ & $1.100 \times 10^{-9}$ & 504 \\
$\mathrm{Ni}(\mathrm{II})$ & - & - & 0.0109 & $9.171 \times 10^{-12}$ & $1.696 \times 10^{-11}$ & 475 \\
$\mathrm{Cu}(\mathrm{II})$ & - & - & 0.0059 & $5.135 \times 10^{-12}$ & $1.005 \times 10^{-11}$ & 478 \\
$\mathrm{Zn}(\mathrm{II})$ & - & 0.0042 & - & $1.435 \times 10^{-11}$ & $5.617 \times 10^{-11}$ & 472 \\
\hline
\end{tabular}

Tc: transition temperature for the ligand and metal complexes; $E_{1}$ : activation energy in the lower temperature; $E_{2}$ : activation energy in the higher temperature; $\sigma_{1}$ : electrical conductivity measured at lower temperature; $\sigma_{2}$ : electrical conductivity measured at higher temperature.

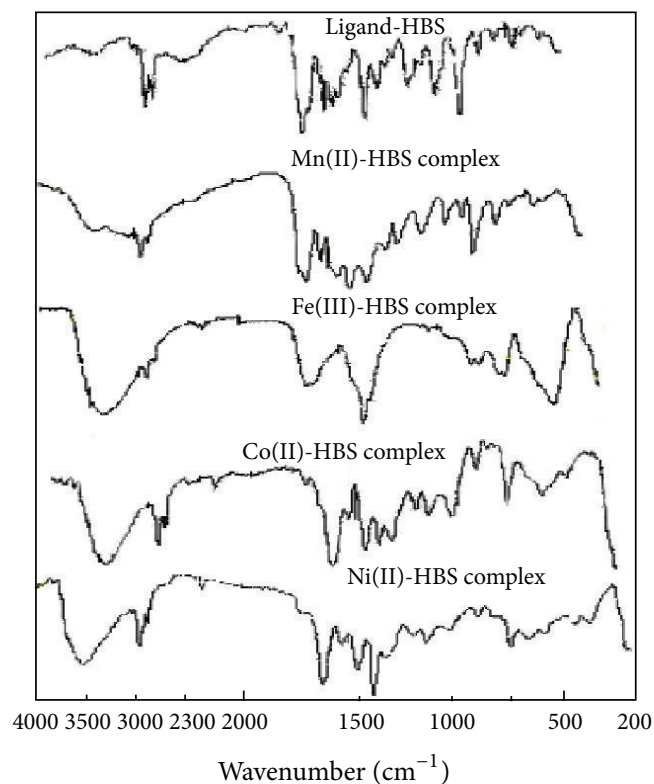

Figure 1: Infrared spectra of L (HBS), Mn(II), Fe(III), Co(II), and $\mathrm{Ni}(\mathrm{II})$-HBS complexes.

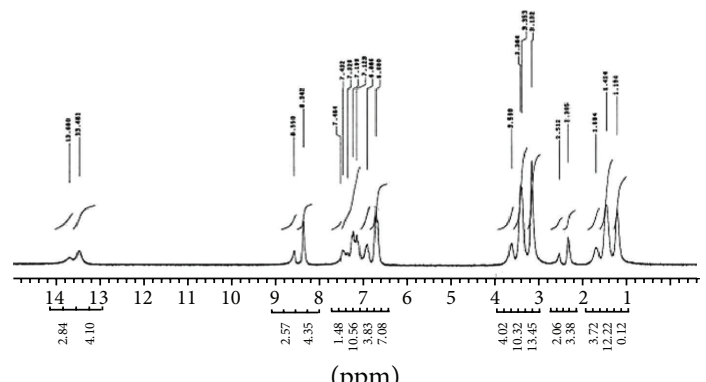

FIGURE 2: ${ }^{1} \mathrm{H}-\mathrm{NMR}$ spectrum of ligand L (HBS).

manner [17]. The monodentate behavior of acetate group in the investigated complex is deduced from the frequency difference $(\Delta v)$ between $v_{\text {asCOO}}{ }^{-}$and $v_{\mathrm{sCOO}^{-}}$. The value is higher than $185 \mathrm{~cm}^{-1}$ indicating a monodentate behavior.

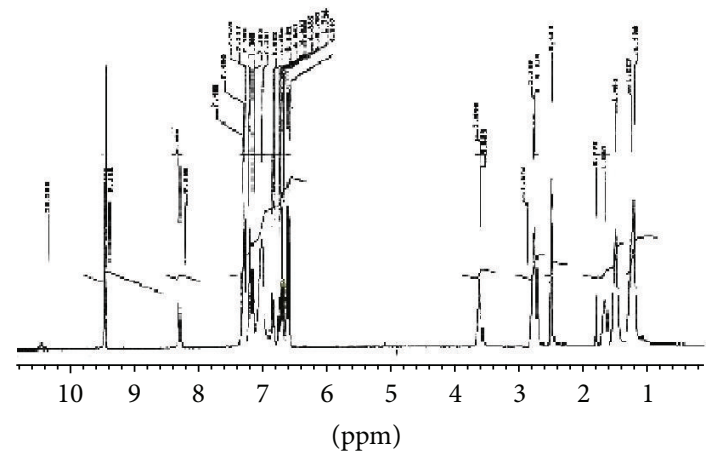

Figure $3:{ }^{1} \mathrm{H}-\mathrm{NMR}$ spectrum of $\left[\mathrm{Zn}_{2}(\mathrm{HL})_{2}(\mathrm{Ac})_{2}\left(\mathrm{H}_{2} \mathrm{O}\right)_{2}\right]$.

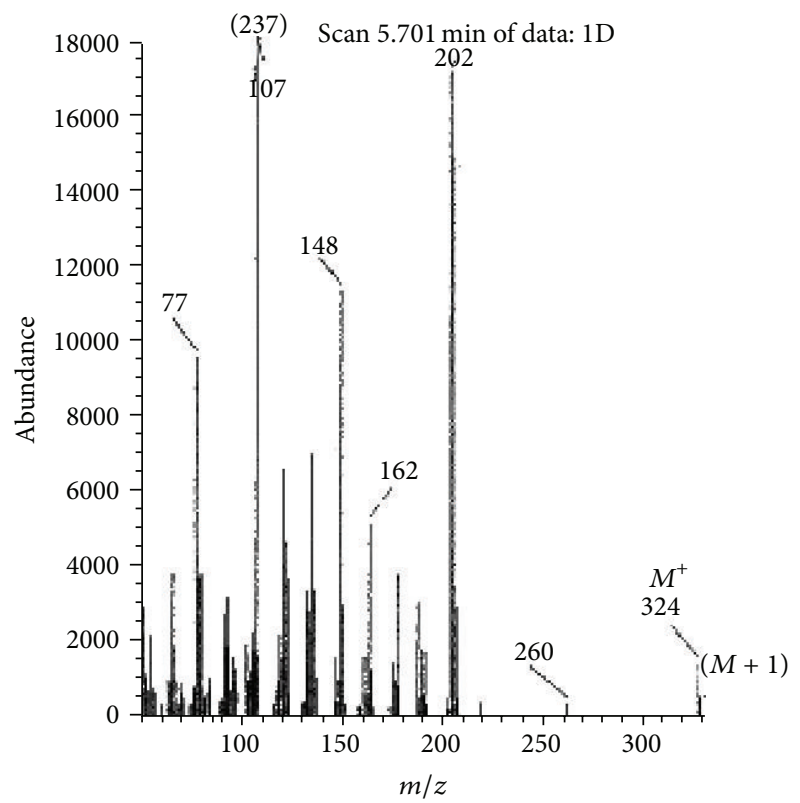

FIgUre 4: Mass spectrum of the Schiff base L (HBS), ligand.

3.3. ${ }^{1} H$-NMR Spectra. The ${ }^{1} \mathrm{H}-\mathrm{NMR}$ of $\mathrm{L}$ shows four types of signals: methylene protons, aromatic protons, hydroxyl, and azomethine proton at $1.194-3.519 \mathrm{ppm}, 6.6-7.4 \mathrm{ppm}$, 8.3-8.5 ppm, and 13.4-13.6 ppm, respectively. The signals of methylene are not influenced corresponding to chelation, but 


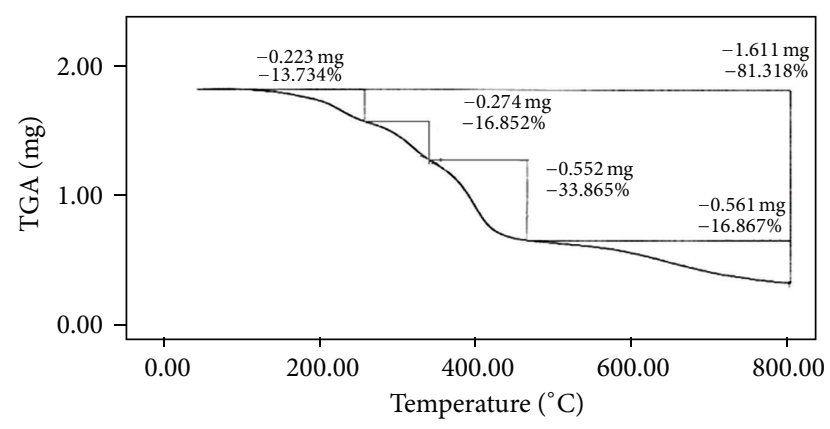

FIgURE 5: TGA curve of $\left[\mathrm{Co}_{2}(\mathrm{HL})_{2}\left(\mathrm{NO}_{3}\right)_{2}\left(\mathrm{H}_{2} \mathrm{O}\right)_{2}\right]$.

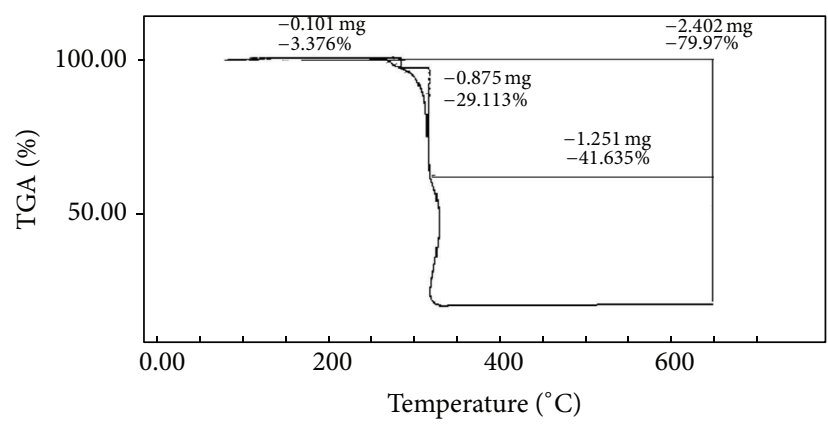

Figure 6: TGA curve of $\left[\mathrm{Cu}_{2}(\mathrm{HL})_{2}(\mathrm{Ac})_{2}\left(\mathrm{H}_{2} \mathrm{O}\right)_{2}\right]$.

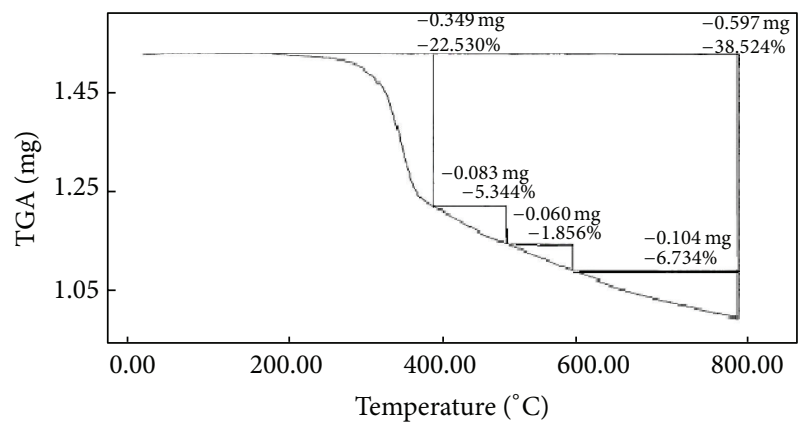

Figure 7: TGA curve of $\left[\mathrm{Zn}_{2}(\mathrm{HL})_{2}(\mathrm{Ac})_{2}\left(\mathrm{H}_{2} \mathrm{O}\right)_{2}\right]$.

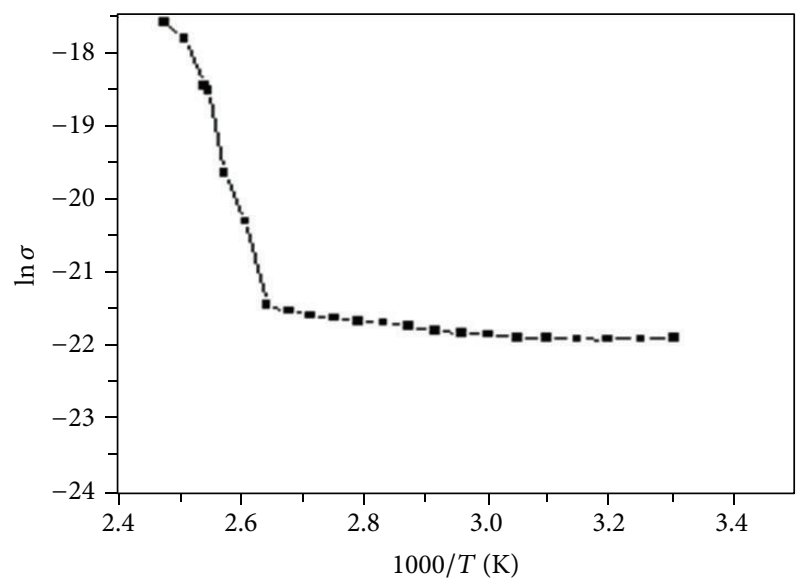

Figure 8: Electrical conductivity of $\left[\mathrm{Mn}_{2}(\mathrm{~L})_{2}\left(\mathrm{H}_{2} \mathrm{O}\right)_{4}\right]$.

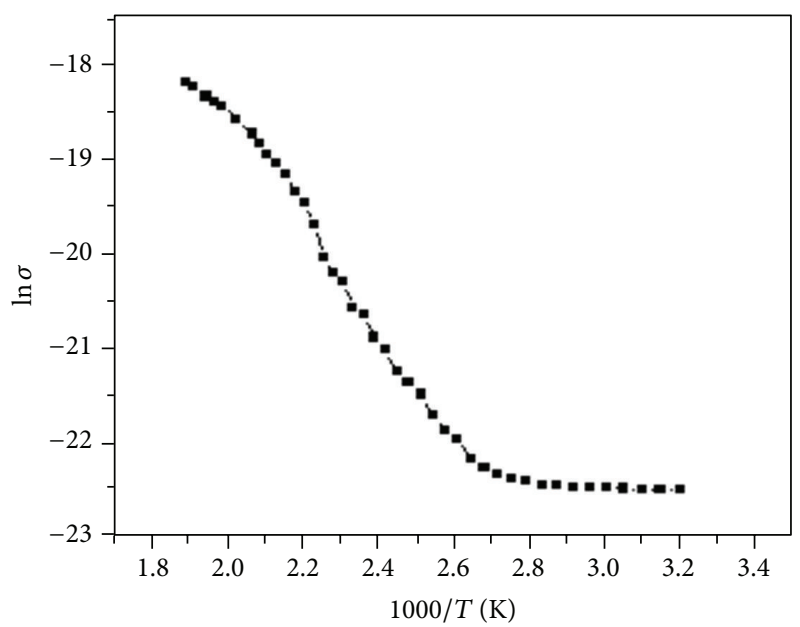

FIGURE 9: Electrical conductivity of $\left[\mathrm{Fe}_{2}\left(\mathrm{H}_{2} \mathrm{~L}\right)\left(\mathrm{NO}_{3}\right)_{6}\left(\mathrm{H}_{2} \mathrm{O}\right)_{2}\right]$ $\cdot 6 \mathrm{H}_{2} \mathrm{O}$.

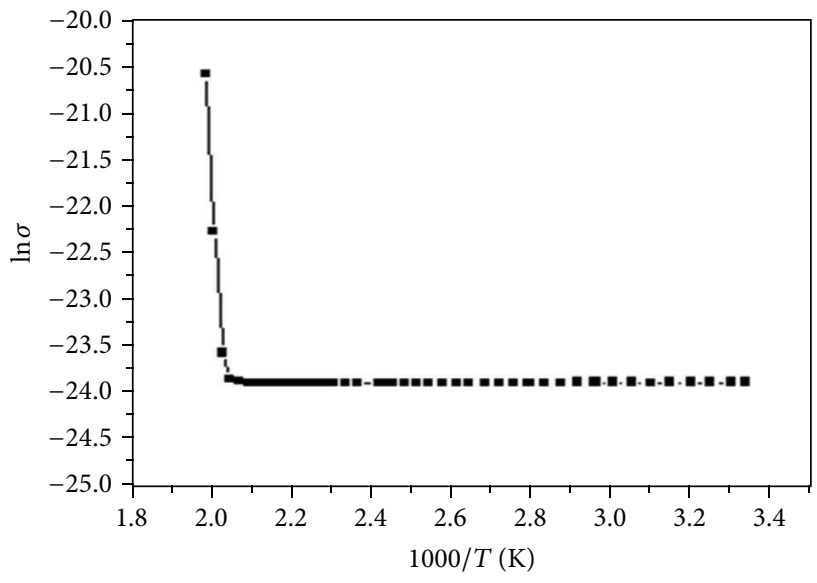

FIGURE 10: Electrical conductivity of $\left[\mathrm{Co}_{2}(\mathrm{HL})_{2}\left(\mathrm{NO}_{3}\right)_{2}\left(\mathrm{H}_{2} \mathrm{O}\right)_{2}\right]$.

the multiplet due to the aromatic protons is broader and shifts to lower field, indicating that the chelation perturbs the electron density distribution through the phenyl ring to some extent. The hydroxyl signal at $13.4 \mathrm{ppm}$ disappeared and azomethine signal was shifted, thus indicating that $\mathrm{CH}=\mathrm{N}$ and $\mathrm{OH}$ group are involved in chelation. Figure 2 depicts ${ }^{1} \mathrm{H}$ NMR of ligand L.

The $\mathrm{Zn}$ (II) complex is diamagnetic as expected, and its geometry is octahedral. The ${ }^{1} \mathrm{H}-\mathrm{NMR}$ spectrum of $\mathrm{Zn}$ (II) complex, $\left[\mathrm{Zn}_{2}(\mathrm{HL})_{2}(\mathrm{Ac})_{2}\left(\mathrm{H}_{2} \mathrm{O}\right)_{2}\right]$ in $\mathrm{CF}_{3} \mathrm{COOD}+\mathrm{DMSO}-$ $\mathrm{d}_{6}$, is shown in Figure 3.

It is observed that the signals of methylene are influenced by chelation, but the multiplet due to the aromatic protons is broader and shifts to lower field, indicating that the chelation perturbs the electron density distribution through the phenyl ring to some extent. The hydroxyl signal and the azomethine signal are shifted, thus indicating that $\mathrm{CH}=\mathrm{N}$ and $\mathrm{OH}$ groups are involved in chelation. 

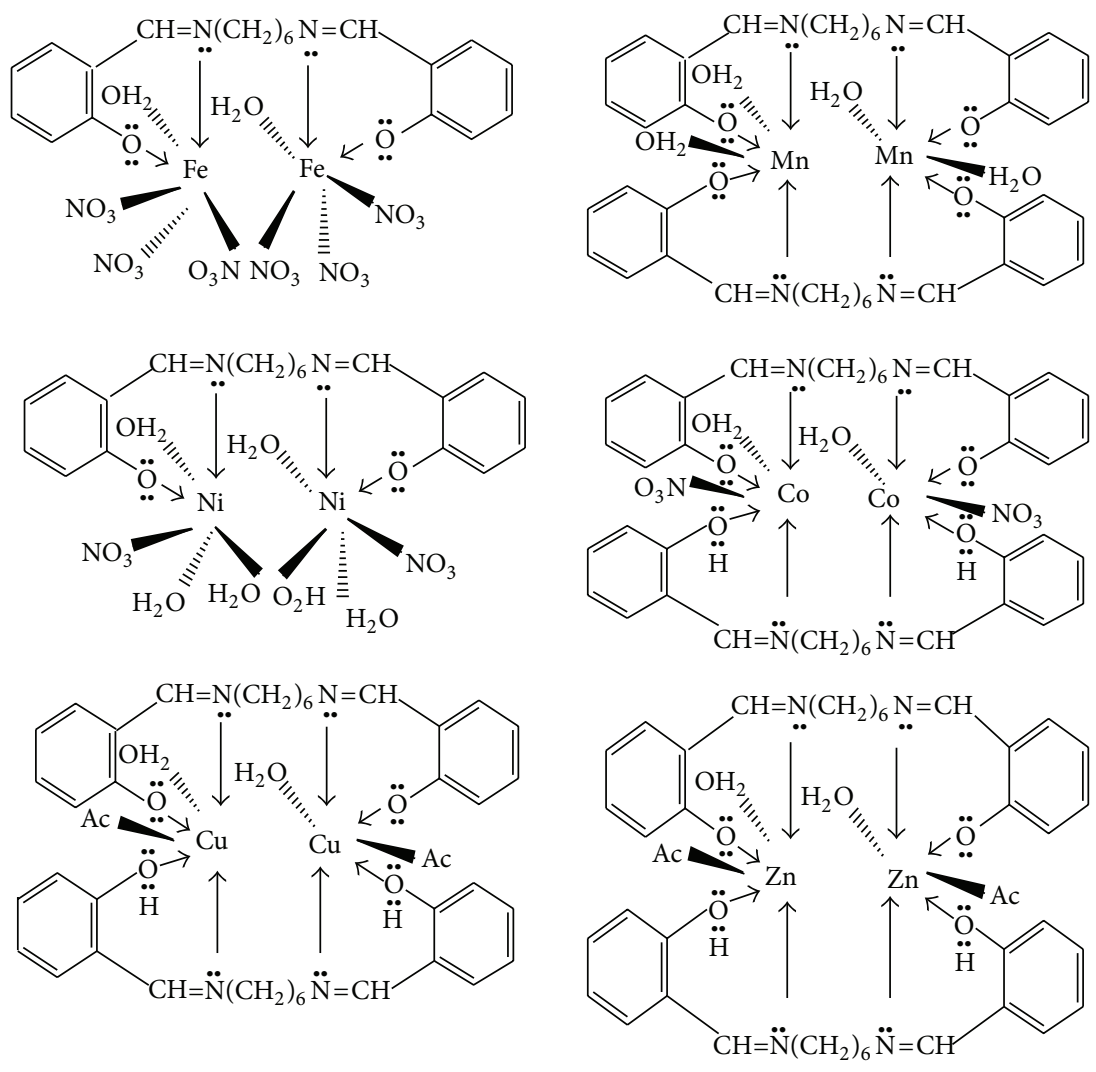

FIGURE 11: Representative structures of $\mathrm{Mn}(\mathrm{II}), \mathrm{Fe}(\mathrm{III}), \mathrm{Co}(\mathrm{II}), \mathrm{Ni}(\mathrm{II}), \mathrm{Cu}(\mathrm{II})$, and $\mathrm{Zn}$ (II)-HBS complexes.

3.4. Mass Spectra. The electron impact mass spectrum of the free ligand confirmed the proposed formula of ligand by showing a peak at 324 due to molecular ion (parent peak). The series of peaks, in the ranges of $65,76,77,91,93,94$, $107,123,121,121,119,120,134,148,162,176,190,204,230$, and 231, may be corresponding to various fragments, and their intensity gives an idea of stability fragments (Figure 4). Mechanism Scheme 2. The mass spectrum of $\mathrm{Co}$ (II) complex, $\left[\mathrm{Co}_{2}(\mathrm{HL})_{2}\left(\mathrm{NO}_{3}\right)_{2}\left(\mathrm{H}_{2} \mathrm{O}\right)_{2}\right]$, the proposed formula of the complex by showing a base peak at $381.9 \mathrm{~m} / z$. The series of peaks at 380.9, 364.9, 288.9, 261.9, 247.9, 233.9, 219.9, 205.9, $191.9,177.9,120,119,93,76,77$, and $51 \mathrm{~m} / z$ may correspond to various fragments, and their intensity gives an idea of the stability of these fragments. The mass fragmentation pattern of $\left[\mathrm{Co}_{2}(\mathrm{HL})_{2}\left(\mathrm{NO}_{3}\right)_{2}\left(\mathrm{H}_{2} \mathrm{O}\right)_{2}\right]$ is depicted in Scheme 3 .

The mass spectrum of $\mathrm{Ni}(\mathrm{II})$ complex $\left[\mathrm{Ni}_{2}(\mathrm{~L})\left(\mathrm{NO}_{3}\right)_{2}\left(\mathrm{H}_{2} \mathrm{O}\right)_{6}\right]$ confirms the proposed formula of the complex by showing a base peak at $380.7 \mathrm{~m} / z$. The series of peaks at 380.7, 364.7, 288.7, 261.7, 247.7, 233.7, 218.7, $191.7,177.7,150.7,92,93,77,76$, and $51 \mathrm{~m} / z$ may correspond to the various fragments, and their intensity gives an idea of the stability of these fragments. The mass fragmentation pattern of $\left[\mathrm{Ni}_{2}(\mathrm{~L})\left(\mathrm{NO}_{3}\right)_{2}\left(\mathrm{H}_{2} \mathrm{O}\right)_{6}\right]$ is depicted in Scheme 4 .

3.5. Thermogravimetric Analysis. TGA curve of $\left[\mathrm{Co}_{2}(\mathrm{HL})_{2}\right.$ $\left.\left(\mathrm{NO}_{3}\right)_{2}\left(\mathrm{H}_{2} \mathrm{O}\right)_{2}\right]$ shows four stages. The first one from 25 to $252^{\circ} \mathrm{C}$ corresponds to loss of two coordinated water molecules and $\mathrm{N}_{2} \mathrm{O}_{4}$ (Calc./Found \%; 13.855/13.734\%) from the total weight of the complex. The second stage from 252 to $335^{\circ} \mathrm{C}$ corresponds to the loss of $\mathrm{C}_{7} \mathrm{H}_{5} \mathrm{NO}_{2}$ (Calc./Found \%; $16.964 / 16.852 \%)$. Third stage from 335 to $359^{\circ} \mathrm{C}$ corresponds to the loss of $\mathrm{C}_{14} \mathrm{H}_{18} \mathrm{~N}_{2} \mathrm{O}$ (Calc./Found \%; 34.806/33.865\%). The last stage from 359 to $800^{\circ} \mathrm{C}$ corresponds to loss of $\mathrm{C}_{5} \mathrm{H}_{10}$ (Calc./Found \%; 16.248/16.867\%). Figure 5 shows the TGA curve of $\left[\mathrm{Co}_{2}(\mathrm{HL})_{2}\left(\mathrm{NO}_{3}\right)_{2}\left(\mathrm{H}_{2} \mathrm{O}\right)_{2}\right]$.

TGA curve of $\left[\mathrm{Cu}_{2}(\mathrm{HL})_{2}\left(\mathrm{CH}_{3} \mathrm{COO}\right)_{2}\left(\mathrm{H}_{2} \mathrm{O}\right)_{2}\right]$ complex shows three stages. The first one is from 25 to $258^{\circ} \mathrm{C}$ with loss of coordinated water molecules (Calc./Found \%; 3.88/3.38\%) from the total weight of the complex. The second stage from 258 to $296^{\circ} \mathrm{C}$ corresponds to the loss of two acetate groups and $\mathrm{C}_{6} \mathrm{H}_{14} \mathrm{~N}_{2} \mathrm{O}_{2}$ (Calc./Found \%; 29.62/29.11\%). The third stage is from 296 to $650^{\circ} \mathrm{C}$ and due to the gradual decomposition of the complex it corresponds to the loss of $\mathrm{C}_{8} \mathrm{H}_{14} \mathrm{~N}_{2} \mathrm{O}_{2}$ $\& \mathrm{C}_{7} \mathrm{H}_{7}$ (Calc./Found \%; 41.61/41.63\%). Figure 6 shows the TGA curve of $\left[\mathrm{Cu}_{2}(\mathrm{HL})_{2}\left(\mathrm{CH}_{3} \mathrm{COO}\right)_{2}\left(\mathrm{H}_{2} \mathrm{O}\right)_{2}\right]$.

TGA curve of $\left[\mathrm{Zn}_{2}(\mathrm{HL})_{2}\left(\mathrm{CH}_{3} \mathrm{COO}\right)_{2}\left(\mathrm{H}_{2} \mathrm{O}\right)_{2}\right]$ complex shows four stages. The first one from 25 to $400^{\circ} \mathrm{C}$ corresponds to the loss of two coordinated water molecules, two acetate groups, and two $\mathrm{N}=\mathrm{CH}$ (Calc./Found \%; 22.346/22.530\%) from the total weight of the complex. The second stage from 400 to $500^{\circ} \mathrm{C}$ corresponds to the loss of $\mathrm{C}_{3} \mathrm{H}_{6}$ (Calc./Found \%; $5.811 / 5.344 \%)$. The third stage from 500 to $581^{\circ} \mathrm{C}$ corresponds to the loss of $\mathrm{C}_{2} \mathrm{H}_{4}$ (Calc./Found \%; 4.112/3.856\%). The last stage from 581 to $800^{\circ} \mathrm{C}$ corresponds to loss of $\mathrm{C}_{2} \mathrm{H}_{3} \mathrm{~N}$ (Calc./Found \%; 6.280/6.734\%). Figure 7 shows the TGA curve of $\left[\mathrm{Zn}_{2}(\mathrm{HL})_{2}\left(\mathrm{CH}_{3} \mathrm{COO}\right)_{2}\left(\mathrm{H}_{2} \mathrm{O}\right)_{2}\right]$. 
3.6. The Electrical Conductivity of the Metal Complexes of Ligand L (HBS). The values of the electrical conductivity $(\sigma)$ and activation energies of the metal complexes of ligand $\mathrm{L}$ (HBS) with $\mathrm{Mn}(\mathrm{II}), \mathrm{Fe}(\mathrm{III}), \mathrm{Co}(\mathrm{II})$, and $\mathrm{Ni}(\mathrm{II})$ are collected in Table 4. They lie in the range of semiconducting materials. The activation energy of thermal decomposition step is determined from the slope of the straight line of $\ln \sigma$ and $1 / T$ (K) relationship. Blotting $\ln \sigma$ against $1 / T(\mathrm{~K})$, as shown in Figures 8,9 , and 10 , of the investigated complexes yielded two lines over the given temperature ranges and obeyed Arrhenius equation. This may be due to phase transition or packing or change of chemical structure during the increase of temperature.

\section{Conclusion}

In conclusion, the Schiff bases derived from 1,6-hexanediamine are bonded to the metal ions as tetradentate ligand. The two bonding sites are the oxygen of the deprotonated hydroxyl group of benzene ring and nitrogen of azomethine which lead to stable six-membered chelating ring. The experimental data suggest the structure shown in Figure 11 for metal chelates under investigation.

\section{References}

[1] S. M. Nelson, "Developments in the synthesis and coordination chemistry of macrocyclic Schiff base ligands," Pure and Applied Chemistry, vol. 52, no. 11, p. 2461, 1980.

[2] D. H. Bush, A. L. Vance, and A. G. Kolchinski, Comprehen-Sive Supramolecular Chemistry, vol. 9, Pergamon, Oxford, UK, 1996.

[3] A. L. Vance, N. W. Alcock, J. A. Herppert, and D. H. Busch, "An octahedral template based on a new molecular turn: synthesis and structure of a model complex and a reactive, diphenolic ligand and its metal complexes," Inorganic Chemistry, vol. 37, p. 6912, 1998.

[4] I. R. Ziessel, "Schiff-based bipyridine ligands. Unusual coordination features and mesomorphic behaviour," Coordination Chemistry Reviews, vol. 216-217, pp. 195-223, 2001.

[5] L. Douce, A. El-Ghayoury, A. Skoulios, and R. Ziessel, "Columnar mesophases from tetrahedral copper(I) cores and Schiffbase derived polycatenar ligands," Chemical Communications, no. 20, pp. 2033-2034, 1999.

[6] A. H. Kianfara, S. Zargari, and J. Khavasi, "Synthesis and electrochemistry of $\mathrm{M}$ (II) $\mathrm{N}_{2} \mathrm{O}_{2}$ schiff base complexes: X-Ray structure of $\{\mathrm{Ni}[\mathrm{Bis}(3-$ chloroacetylacetone)ethylenediimine]\}," Journal of the Iranian Chemical Society, vol. 7, pp. 908-916, 2010.

[7] Z.-L. You and H.-L. Zhu, "Syntheses, crystal structures, and antibacterial activities of four schiff base complexes of copper and zinc," Zeitschrift für anorganische und allgemeine Chemie, vol. 630, no. 15, pp. 2754-2760, 2004.

[8] A.-N. M. A. Alaghaz, H. A. Bayoumi, Y. A. Ammar, and S. A. Aldhlmani, "Synthesis, characterization, and antipathogenic studies of some transition metal complexes with N,O-chelating Schiff's base ligand incorporating azo and sulfonamide Moieties," Journal of Molecular Structure, vol. 1035, pp. 383-399, 2013.
[9] H. A. Bayoumi, A.-N. M. Alaghaz, and M. Sh. Aljahdali, "Cu(II), Ni(II), $\mathrm{Co}(\mathrm{II})$ and $\mathrm{Cr}(\mathrm{III})$ complexes with $\mathrm{N}_{2} \mathrm{O}_{2}$ chelating Schiff's base ligand incorporating Azo and sulfonamide moieties: spectroscopic, electrochemical behavior and thermal decomposition studies," International Journal of Electrochemical Science, vol. 8, pp. 9399-9413, 2013.

[10] A. F. Kolodziej, “The chemistry of nickel-containing enzymes," Progress in Inorganic Chemistry, vol. 41, pp. 493-597, 1994.

[11] R. R. Parasher, R. C. Sharma, A. Kumar, and G. Mohan, "Stability studies in relation to IR data of some schiff base complexes of transition metals and their biological and pharmacological studies," Inorganica Chimica Acta, vol. 151, pp. 201-208, 1988.

[12] S. Biswas, K. Mitra, C. H. Schwalbe, C. R. Lucas, S. K. Chattopadhyay, and B. Adhikary, "Synthesis and characterization of some $\mathrm{Mn}(\mathrm{II})$ and $\mathrm{Mn}(\mathrm{III})$ complexes of $N, N^{\prime}$-o-phenylenebis(salicylideneimine) $\left(\mathrm{LH}_{2}\right)$ and $N, N^{\prime}$-o-phenylenebis(5bromosalicylideneimine $\left(\mathrm{L}^{\prime} \mathrm{H}_{2}\right)$. Crystal structures of $[\mathrm{Mn}(\mathrm{L})$ $\left.\left(\mathrm{H}_{2} \mathrm{O}\right)\left(\mathrm{ClO}_{4}\right)\right],[\mathrm{Mn}(\mathrm{L})(\mathrm{NCS})]$ and an infinite linear chain of $[\mathrm{Mn}(\mathrm{L})(\mathrm{OAc})]$," Inorganica Chimica Acta, vol. 358, no. 8, pp. 2473-2481, 2005.

[13] A. B. P. Lever, Inorganic Electronic Spectroscopy, Elsevier, New York, NY, USA, 2nd edition, 1984.

[14] K. Nakamoto, Infrared and Raman Spectra of Inorganic and Coordination Compounds, Wiley Interscience, New York, NY, USA, 1970.

[15] D. X. West, A. A. Nassar, F. A. El-Saied, and M. I. Ayad, "Cobalt(II) complexes with 2-aminoacetophenone N(4)substituted thiosemicarbazones," Transition Metal Chemistry, vol. 24, no. 6, pp. 617-621, 1999.

[16] S. Chandra and U. Kumar, "Spectral studies of coordination compounds of cobalt(II) with thiosemicarbazone of heterocyclic ketone," Spectrochimica Acta Part A, vol. 62, pp. 940-944, 2005.

[17] S. Kivscher, Journal of theAmerican Chemical Society, vol. 28, no. 2372, 1956. 

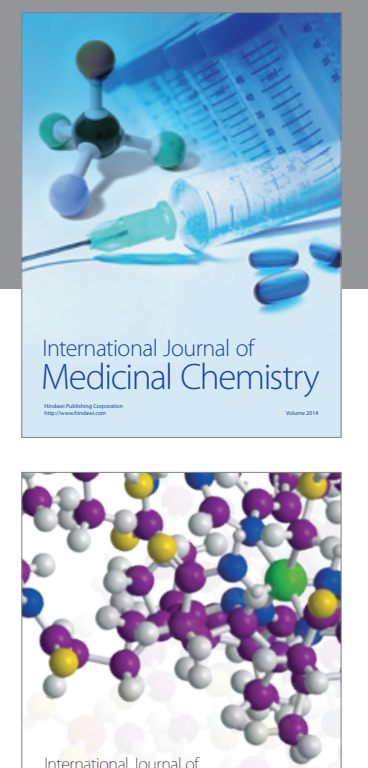

\section{Carbohydrate} Chemistry

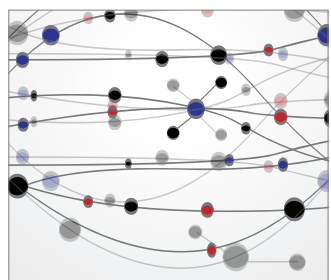

The Scientific World Journal
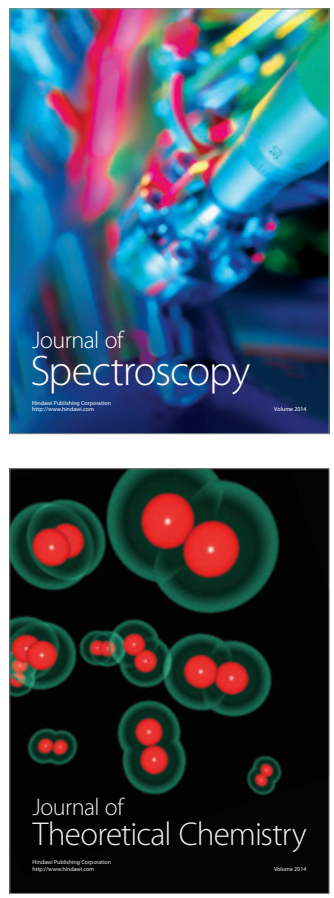
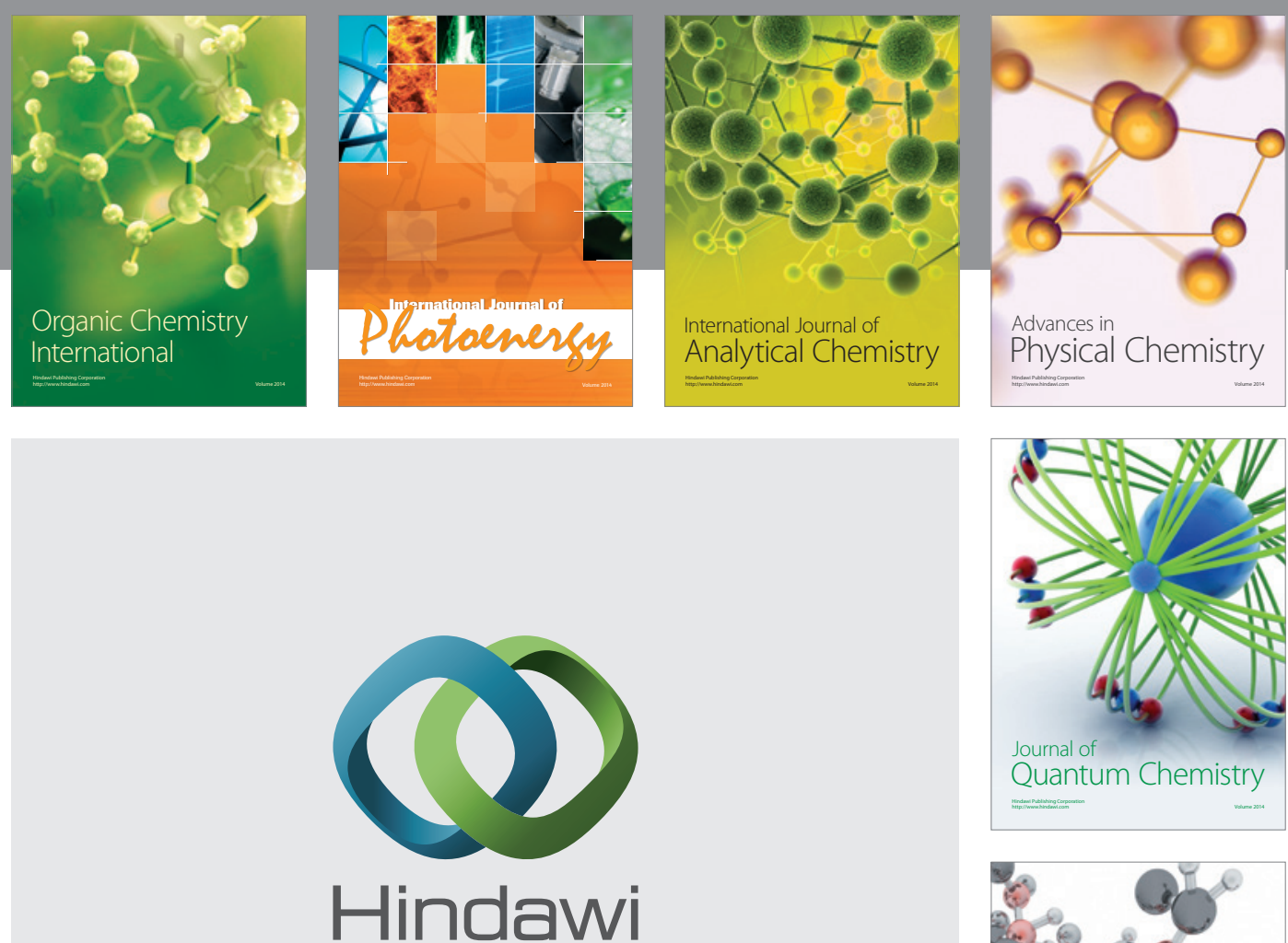

Submit your manuscripts at

http://www.hindawi.com

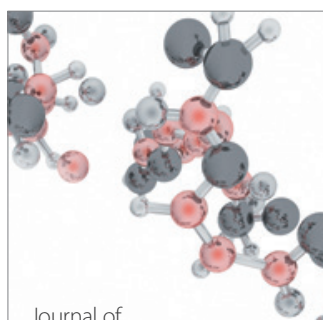

Analytical Methods

in Chemistry

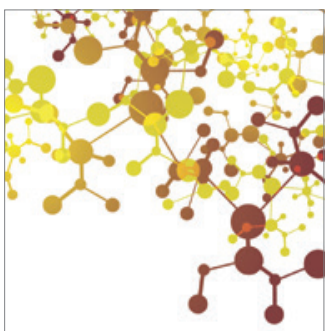

Journal of

Applied Chemistry

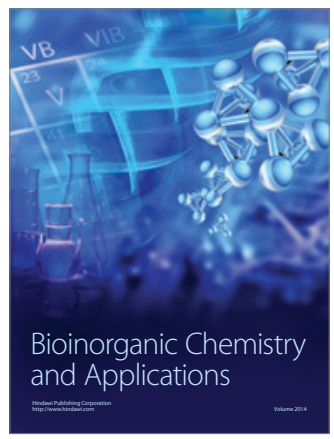

Inorganic Chemistry
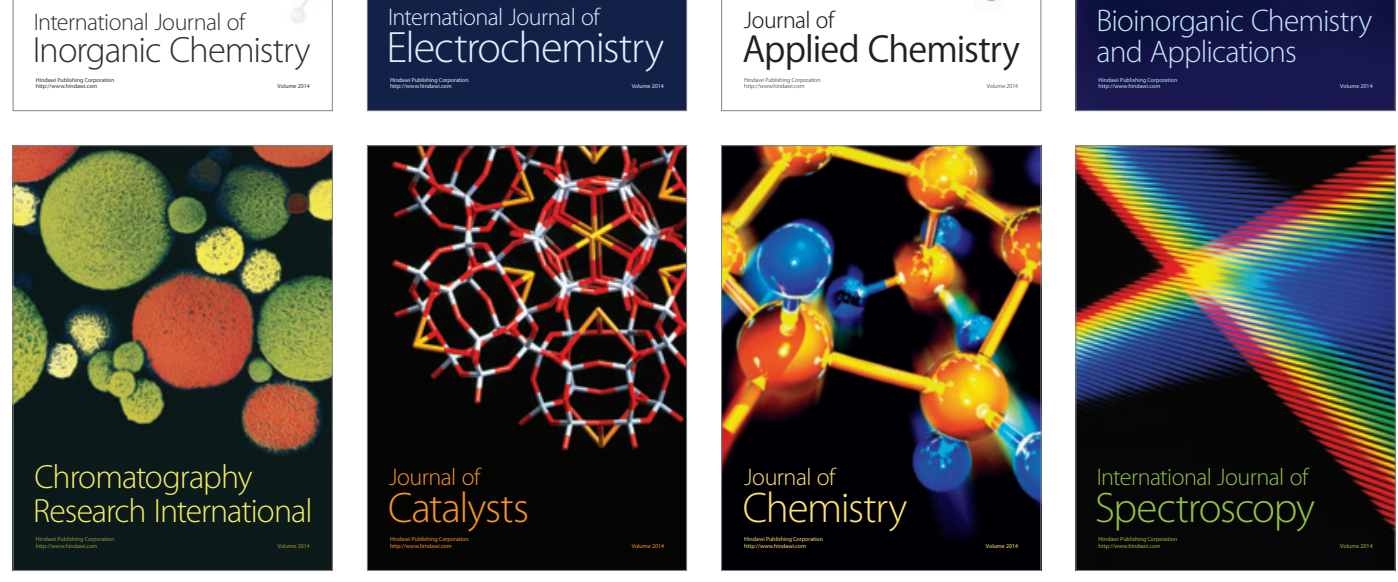